\title{
Havacılık ve Meteoroloji
}

\author{
Fahrettin Öztürk ${ }^{1 *}$, Hüseyin Fazla ${ }^{2}$, Rukiye Aybüke Akbay $^{3}$, Temel Kotil $^{4}$ \\ $1^{*}$ Ankara Yıldırım Beyazıt Üniversitesi, Mühendislik ve Doğa Bilimleri Fakültesi, Makine Mühendisliği Bölümü, Ankara, Türkiye (ORCID: 0000-0001-9517-7957), \\ fahrettin71@gmail.com \\ 2 Türk Havacılık ve Uzay Sanayii A.Ş., Ankara, Türkiye, (ORCID: 0000-0002-5935-1978), huseyin.fazla@tai.com.tr \\ 3 Türk Havacılık ve Uzay Sanayii A.Ş., Ankara, Türkiye, (ORCID: 0000-0001-9370-2084), rukiyeaybuke.aydemir@tai.com.tr \\ ${ }^{4}$ Türk Havacılık ve Uzay Sanayii A.Ş., Ankara, Türkiye, (ORCID: 0000-0002-9575-6155), temel.kotil@tai.com.tr
}

(İlk Geliş Tarihi 19 Ocak 2021 ve Kabul Tarihi 4 Haziran 2021)

(DOI: $10.31590 /$ ejosat.862929)

ATIF/REFERENCE: Öztürk, F, Fazla, H., Akbay, R. A. \& Kotil, T. (2021). Havacılık ve Meteoroloji. Avrupa Bilim ve Teknoloji Dergisi, (25), 131-138.

\begin{abstract}
Öz
Meteoroloji hayatımızın her alanında yer almakta ve birçok sektörde belirleyici rol oynamaktadır. Bu sektörlerin en önemlilerinden birisi olan havacılıkta atmosferik şartları gerçek zamanlı gösteren meteoroloji bilgisi çok büyük öneme sahiptir. Hem hava trafiği hem hava araçlarının üretimine yönelik yatırımlar anlamında meteoroloji daima ön planda tutulmaktadır. Bu çalışma kapsamında havacılığımız açısından havacılık meteorolojisi detaylıca incelenmiştir. Meteoroloji politikaları nasıl olmalıdır? Nasıl stratejiler geliştirilmelidir? Havacılık ve meteoroloji ilişkileri nasıl düzenlenmelidir? soruları tartışılmıştır. Güçlü bir havacılık için güçlü bir teknolojisi olan meteoroloji sistemlerine sahip olunmasının gerekliliği vurgulanmıştır. Havacılık yatırımları yapılırken meteorolojik bilgilerin dikkate alınması çok büyük öneme sahiptir. Havacılık Endüstrisi ile Meteoroloji Genel Müdürlüğü ortak çalışmalar yaparak ortak politikalar ve stratejiler belirlemelidir.
\end{abstract}

Anahtar Kelimeler: Havacılık; Havacılık Politikaları; Meteoroloji; Meteoroloji Stratejileri.

\section{Aviation and Meteorology}

\begin{abstract}
Meteorology takes place in all areas of our lives and plays a decisive role in many sectors. Aviation is one of the most important of these sectors requires meteorological information shows atmospheric conditions in real time is great importance. Meteorology is always prioritized in terms of both air traffic and investments for the production of aircraft. Within the scope of this study, aviation meteorology has been examined in detail in terms of our aviation. How should meteorology policies be? What strategies should be developed? How should aviation and meteorology relations be regulated? questions are discussed. The necessity of having meteorology systems, which is a powerful technology for a strong aviation, is emphasized. It is of foremost importance to consider meteorological information when making aviation investments. Aviation Industry and the General Directorate of Meteorology should work together to determine common policies and strategies.
\end{abstract}

Keywords: Aviation; Aviation Policies; Meteorology; Meteorology Strategies.

\footnotetext{
* Sorumlu Yazar: fahrettin71@gmail.com
} 


\section{Giriș}

Ülkemizin havacılık tarihinin köklü bir geçmişi vardır. İlk faaliyetler II. Abdülhamid dönemine dayanmakta olup, bu dönemde Fransa'ya balon siparişi verilmiştir (Dervişoğlu, 2014). Osmanlının son dönemlerinde de farklı ülkelerden 20 civarı değişik tip uçak temin edilmiş ve Hava Kuvvetleri güçlendirilmiştir (teyyareci.com, 2020). Osmanlı dönemindeki havacılık faaliyetleri, ordu bünyesinde "Umur-u Havaiye Müfettişliği”, Millî Mücadele sırasında "Kuva-i Havaiye Şubesi”, Cumhuriyet kurulduğunda ise "Hava Müfettişliği" ismiyle anılmıştır. 1928 yılında "Hava Müsteşarlığı" kurulmuş, havacılığın önemine binaen 1944 yılında "Hava Kuvvetleri Komutanlığı" teşkil edilmiştir (Dervişoğlu, 2014). Cumhuriyetin ilk yıllarından itibaren havacılık alanında önemli yatırımlar yapılmış fabrikalar kurulmuş, yurt dışına uçak mühendisliği alanında yetiştirilmek üzere öğrenciler gönderilmiştir. Ulu Önder Atatürk aslında 1925 yılında "İstikbal Göklerdedir" sözüyle stratejimizi belirlemiştir. Hava gücü ve savunması en güçlü olan devletler son yüzyıldaki birçok savaşta gelişmiş hava araçlarına ve silah sistemlerine sahip olan tarafin hava üstünlüğünü kazandığını, havacılığa yatırım yapmayan tarafın "savaşı kazanamayacağını" defalarca ortaya koymuşlardır. Havacılık faaliyetleri Cumhuriyetimizin ilk yıllarında başlamış kesintili de olsa havacılık alanında başarılı hamleler 1950'li yıllara kadar ardı ardına gelmiştir. Sonrasında çeşitli nedenlerle havacılık sanayimizin gelişimi sekteye uğramış, hedeflenen seviyeye bir türlü ulaşılamamıştır. Havacılık alanında yapılan çalışmalar O. Yalçın tarafından yapılan yayında (Yalçın, 2010) detaylı olarak özetlenmiştir.

Bütün bunlara rağmen havacılık bütün Cumhuriyet tarihimiz boyunca her zaman gündemde olmuştur. Günümüzde ülkemizdeki en önemli havacılık sanayii alanındaki faaliyetler Türk Havacılık ve Uzay Sanayii A.Ș. (TUSAŞ) bünyesinde yürütülmektedir. Şirket; 28 Haziran 1973'te TUSAŞ çatısı altında, Türkiye'nin savunma sanayiinde dışa bağımlılığını azaltmak amacıyla, Sanayi ve Teknoloji Bakanlığı bünyesinde kurulmuştur. Türk Hava Kuvvetleri'nin savaş uçağı ihtiyacının karşılanmasına yönelik olarak F-16 uçaklarının kullanılması kararı ile birlikte; F-16 uçağının üretimi, uçak üzerindeki sistemlerin entegrasyonu, uçuş testlerinin yapılması ve sonrasında Hava Kuvvetlerimize teslim etmek maksadıyla, 1984 yılında Havacılık ve Uzay Sanayii A.Ş. (TAI), şimdiki adıyla TUSAŞ, Türk-ABD ortak yatırım şirketi olarak 25 yıllığına kurulmuştur. F-16 üretim süreci tamamlandıktan sonra, başka hava araçlarını da üretebilmesi kapsamında, 2005 yılında TAI'nin yabancı hisseleri Türk hissedarlar tarafından satın alınarak TAI yeniden yapılandırılmıştır. Bu kapsamda TAI ve TUSAŞ birleşerek, TUSAŞ - Türk Havacılık ve Uzay Sanayii A.Ş. çatısı altında faaliyetlerini genişletmiş, havacılık ve uzay sanayi sistemlerinin geliştirilmesi, modernizasyonu, üretimi, sistem entegrasyonu ve yaşam döngüsü destek süreçlerinde Türkiye'nin teknoloji merkezi konumuna gelmiştir (tusas.com, 2020). Havacılık ve uzay sanayisinde küresel ilk 100 oyuncu arasında yer alan TUSAŞ, proje konularına bağlı olarak; Yapısal Grubu, Uçak Grubu, Helikopter Grubu, İnsansız Hava Aracı (İHA) Sistemleri Grubu, Uzay Sistemleri Grubu ve Milli Muharip Uçak (MMU) Grubu'nu bünyesinde barındırmaktadır. TUSAŞ'ın yanı sıra TUSAŞ Motor Sanayii A.Ş. (TEI), BAYKAR, Alp Havacılık, Vestel ve benzeri birçok havacılık firması da ülkemizde havacılık alanında başarılı bir şekilde üretim faaliyetlerini sürdürmektedir.
Son yıllarda ülkemizdeki başarılı havacılık faaliyetlerinin yanı sıra hava trafiğinde de ciddi artışlar görülmektedir. Birçok ilimizde yeni havaalanları açılmakta, hava trafiği çok hızlı şekilde artmaktadır. Havacılık hizmetleri açısından meteoroloji çok büyük öneme sahiptir. Meteorolojik hizmetler hem uçuş emniyeti hem konfor hem de yakıt sarfiyatı açısından havacılık sektörünün ayrılmaz bir parçasıdır. Bilindiği üzere uçuş söz konusu olduğunda uçuş faaliyetlerini, meteorolojik hizmetlerle birlikte değerlendirmek gerekir. Meteoroloji, dünyamızı çevreleyen atmosferi ve atmosferde meydana gelen değişiklikleri inceleyen bir bilim dalıdır. Meteorolojik bilgi ve verilerden yararlanarak uçuşların planlanması da emniyetli, konforlu ve rahat bir yolculuk için gerekli ön şarttır. Aynı şekilde iniş ve kalkışlardaki meteorolojik bilgiler pilotlar için önemlidir. Özellikle meydanlardaki görüş mesafesi, pist görüş mesafesi, bulut alt taban yüksekliği, yağışın şekli ve şiddeti, altimetrik basınç değeri, rüzgâr hızı ve yönü, türbülans ve rüzgar kayması (windshear) gibi meteorolojik bilgiler uçakların emniyetli iniş ve kalkış yapmalarında en önemli etkenlerdendir (Jeppesen, 2004). Uçuş faaliyetleri bakımından önem arz eden bu meteorolojik parametrelerin gözlemlenmesi amacıyla Uluslararası Sivil Havacılık Teşkilatının kriterlerine göre, her havaalanında ulusal veya uluslararası meteorolojik bilgi taleplerini karşılayabilecek en az bir meteoroloji ofisinin bulunması zorunludur. Havacılık işletmeciliği bakımından meteoroloji hizmetine duyulan ihtiyaç üç grup altında değerlendirilebilir. Uçuş Planlama Safhası: Alınacak yakıt yük miktarının belirlenmesi ve alternatif havaalanlarının belirlenmesi. Uçuş Safhası: Yol boyunca karşılaşılması muhtemel hava olaylarının (türbülans, buzlanma, oraj vs.) önceden belirlenerek tedbir alınması. Kalkış ve İniş Safhası: Tehlike oluşturabilecek yan rüzgâr, bulut alt taban yüksekliğinin bilinmesi, düşük görüş mesafesinin bilinerek iniş ve kalkış planlaması. Bu hususlar dikkate alındığında uçuş faaliyetleri meteoroloji ile doğrudan ilgilidir. $\mathrm{Bu}$ açıdan bakıldığında havacılık ve meteoroloji birimlerinin birlikte çalışmak zorunda olduğu görülür. Ortak bir sinerjiyle birlikte çalışmak, projeler gerçekleştirmek ve yenilikleri uygulamak ülkemiz için çok büyük öneme sahiptir. Güçlü bir havacılık için çok güçlü bir meteoroloji alt yapısı ve bilgi aktarımı gereklidir. Bu kapsamda havacılıkta meteoroloji, ortak strateji ve politikalar bu çalışmamız dahilinde incelenmektedir.

\section{Havacilıkta Meteoroloji}

Uçucular için meteoroloji bilimine hâkim olunması bir zorunluluktur, zira atmosfer hava aracının uçtuğu mekân olup, meteorolojik hadiselerin cereyan ettiği bir ortam olan atmosferi bilmeden uçuşların icra edilmesi söz konusu olamaz. Hava aracının izleyeceği rota (yol) boyunca meteorolojik hadiseleri bilmek gerektiği gibi, uçuş esnasında ne tür hava hadiselerinin gelişmekte olduğuna dair tahmin bilgisine ve bu tahmine göre hava aracının emniyetle uçurulabilmesine, gerektiğinde meteorolojik tahminler doğrultusunda uçuş planlamalarının yenilenmesine, hatta uçuşların iptal edilmesine kadar varan bir sürecin pilotlar, uçuş planlamacıları, hava aracı sahipleri ve ilgili uzmanlar tarafından işletilmesi gerekebilir. Bilindiği üzere Atmosferin en alt tabakası troposferdir. Yeryüzünden yaklaşık 36.000 feete (11.000 metre) kadar olan bölgeye troposfer denir. Troposferin üzerinde stratosfer olup, yaklaşık 150.000 feete (50.000 metre) uzanır. Uçuş faaliyetleri çoğunlukla troposfer içinde ve çok az bir kısmı stratosferin alt kısmında gerçekleşmektedir (Jeppesen, 2004). Bu birleşik bölge, Havacılık 


\section{Avrupa Bilim ve Teknoloji Dergisi}

Atmosferi (aviation atmosphere) olarak isimlendirilir. Meteorolojinin uçuş faaliyetlerini doğrudan etkileyen rüzgâr, türbülans, sıcaklık, sis, yağışlar, don ve buzlanma gibi olayları gözlemleyen ve tahminlerde bulunan dalı Havacılık Meteorolojisi olarak isimlendirilir. Uçak Teknisyenleri Derneğinin (UTED) resmi yayını UTED Dergi'sinde

"Havacllı, meteorolojik olaylara son derece duyarlı bir sektördür. Hava koşullarının uçuşlar üzerinde doğrudan bir etkiye sahip olması, hızla büyüyen sektörde göz ardı edilemeyecek bir unsur olarak "Havacılık Meteorolojisi" kavramının ortaya çıkmasına sebep olmuştur. Uluslararası Sivil Havacılık Teşkilatı (ICAO) esaslarına göre de meteorolojik hizmetlerle ilgili uluslararasi kodlama ve standartlar belirlenmiştir. Bu ihtiyaca yönelik olarak radarlar ilk kez 1950 \%i yllarda meteoroloji alanında kullanılmaya başlandı. 1970`lerden itibaren de Doppler radar teknolojisi kullanılarak radarlardan dijital formda bilgilere ulaşıldı." (UTED Dergi, 2020) bilgileri verilerek tanımlama yapılmıştır. Havacılık meteorolojisi sistemin en önemli çarklarından birisidir.

Yüksek irtifalarda jet stream denen kuvvetli rüzgârlar hava araçlarının uçuş rota hesaplamalarında göz önüne alınması gereken önemli bir faktördür. Jet rüzgârları yakıt planlaması ile doğrudan ilgilidir. Hava aracı kuvvetli baş rüzgârı (head-wind) alıyorsa varış noktasına sakin bir rüzgâr etkisinde ulaşacağından daha uzun sürede ulaşır. Yakıt planlaması açısından bakıldığı zaman kuvvetli baş rüzgârı ekonomik açıdan negatif etki yapmaktır. Hava aracı kuvvetli kuyruk rüzgârına (tail-wind) maruz kalıyorsa bu durumda rüzgâr hareketi destekleyici bir etmen olacaktır. Böylece, yakıt tüketimi azaltmakta ve zamandan da tasarruf edilmektedir. Jet rüzgârları ile ilgili dikkat edilmesi gereken en önemli nokta, bu rüzgârları uçuş rotası boyunca yan rüzgâr olarak almaktan kaçınmaktır.

Uluslararası Sivil Havacılık Teşkilatı (ICAO) deniz seviyesini standart atmosferik seviye olarak kabul eder ve ortalama deniz seviyesindeki hava sicaklığ $15^{\circ} \mathrm{C}$ olarak kabul edilir. Hava sıcaklığının yükseklikle değişimi "lapse rate" olarak tanımlanır. Atmosferin en alt tabakası olan Troposferde lapse rate genellikle $-6,5^{\circ} \mathrm{C} / \mathrm{km}$ 'dir. Kısacası yerden yükseldikçe her 1.000 metrede sıcaklık $6,5{ }^{\circ} \mathrm{C}$ düşer. Benzer değişim durumu basınç değeri için de geçerlidir. Deniz seviyesinde standart atmosferik basınç 1013,25 hPA olup, 30.000 feette yaklaşık 300 hPA'dır. Kuzey yarımkürede rüzgarlar saat istikametinin aksi yönünde ve aynı zamanda kuzey kutbuna doğru eserken, Güney yarımkürede bunun tersi bir durum seyreder. Atmosferde termik ve dinamik kaynaklı hava hareketlerine bağlı olarak alçak (siklon) ve yüksek basınç (antisiklon) bölgeleri oluşur. Bu farklı basınç bölgeleri (sıcak cephe, soğuk cephe vb.) arasında geçişler meteorolojik hadiselerin hızlı veya yavaş gelişimini tetikler (Jeppesen, 2004). Siklonlarda hava hareketi yükselici yani konveksiyonel bir özellik gösterir. Antisiklonlarda ise hava hareketi alçalıcı yani sübsidans şeklindedir. Aynı şekilde dağlık arazi üzerindeki rüzgar değişimleri ile deniz üzerindeki rüzgar değişimleri de birbirinden farklıdır.

Sayılamayacak çeşitlilikteki bu tür atmosferik hadiselerdeki değişim havacılık açısından neden önemlidir? Bir örnek vermek gerekirse, uçak motorlarının sıcaklık, basınç gibi değişkenlerden en az etkilenecek şekilde tasarlanması, motorların her irtifada mümkün olduğunca verimliliğini koruyabilmesi, en önemlisi pilotların ve yolcuların emniyetle bir yerden bir yere atmosferde seyahat edebilmesi için atmosferdeki değişimlerden en az etkilenecek ve her hava şartında emniyetle uçağın uçurulmasına imkân verecek şekilde uçakların üretiminin gerçekleştirilmesi bir zorunluluktur. Burada en önemli husus uçağın uçtuğu coğrafyaya uygun tasarımın yapılmasının önemi aşikardır. Tasarımcı motor seçerken, turbo sistemi seçerken uçağın güvenli uçacağı irtifayı göz önünde bulundurmak zorundadır. Sonuç olarak hava aracı tasarlarken mutlaka meteorolojik veriler göz önünde bulundurulmalıdir.

Ortamdaki havanın sıcaklığı, basınç ve nem koşulları havanın yoğunluğunu belirler. Diğer tüm faktörlerin değişmediği varsayımıyla hareket edildiğinde, bir havaalanının rakımındaki artma, ortalama basıncı azaltır ve bu durum ortalama hava yoğunluğuna etki eder. $\mathrm{Bu}$ nedenle yüksek rakımlı havaalanlarında daha uzun kalkış mesafelerine, dolayısıyla deniz seviyesindeki meydanlara göre bu havaalanlarının pistlerinin daha uzun inşa edilmesine ihtiyaç duyulur. Hava yoğunluğundaki azalmanın diğer bir etkisi de motor gücünü düşürmesi ve taşıma ve sürükleme kuvvetlerini azaltmasıdır (050 Meteoroloji, 2007). $\mathrm{Bu}$ nedenle yoğunluk irtifası ile taşıtın performansı "ters orantılıdır". Örneğin bir uçak ortalama deniz seviyesine göre 1000 feet irtifada uçmasına rağmen, atmosferik koşullardan dolayı o irtifaya karşılık gelen yoğunluk irtifası 2500 feet ise, uçağın performansı 2500 feet seviyesinde uçuyormuş gibi (daha düşük) gerçekleşecektir (Dorothy and Robson, 2010)

Havacılıkta bulutluluk önemli bir faktördür. Sis, pus gibi görüş mesafesini düşüren su buharı yoğunlaşmasıyla oluşan "bulutlanma", hava araçlarının meteorolojik hadiselerden kaynaklı olarak iniş ve kalkış esnasında problem yaşamasına neden olur. Özellikle sisli, puslu havalarda görüş mesafesinin bilinmesi, uçakların emniyetle inişe geçmesi veya kalkış yapması kararlarının alınmasında en önemli faktörlerden birisidir. İnsan gözü özellikle gece şartlarında görüş mesafesini ölçmede yanılmaya, hata yapmaya meyillidir. $\mathrm{Bu}$ nedenle görüş mesafesinin teknik bir aletle (transmissometer) ölçülerek, pilotlara iniş veya kalkışta ne kadar bir görüş mesafesinde uçaklarını kullanabilecekleri bilgisi önceden hava rasatlarıyla veya anlık ölçümlerle bildirilmiş olur. Özellikle inişe gelen uçakların kötü hava şartlarında problem yaşamadan inebilmeleri için Aletli İniş Sistemi (Instrument Landing System - ILS) kullanılarak, pilotların meydana yaklaşırken hem belirli bir süzülüş açısıyla emniyetle yaklaşması hem de meydanı 50 feet yanca ve 27 feet dikeyce görebilecekleri noktaya kadar uçaklarını emniyetle kullanabilmeleri sağlanır. Bunun için meydanlarda ILS olması gerektiği gibi uçakların da ILS ile iletişimini sağlayan, pilotun kokpitteki göstergeler üzerinden uçağını ILS hattına sokmasını sağlayan uçuş aletlerinin uçaklarda bulunması gerekir. ILS alçalma noktalarına pilotun emniyetle gelebilmesi için uygun hassasiyete sahip seyrüsefer kolaylıklarına, uçaktaki INS (Inertial Navigation System), GPS (Global Positioning System) gibi sistemlerin varlığına, trafik bilgisi/yönlendirmesi yapabilecek yeterlilikte yer radarlarına ihtiyaç bulunur.

Meydanlardaki ILS sistemleri yanında modern yolcu jetlerinin tamamında, tehlikeli sayılabilecek şekilde ani bir biçimde yere veya bir arazi engeline yaklaşılması durumunda pilotları uyaran GPWS (Ground Proximity Warning System) adlı sistem bulunmaktadır. İlk olarak 1974 yılında kullanıma sunulan bu sistem sayesinde, özellikle görüşün düşük olduğu alçak irtifa şartlarında, meydana yaklaşma ve iniş safhasında olası pilot hatalarından kaynaklanan kazaların önüne geçilmesi amaçlanmıştır (Gök, 2015).

Meydanlara iniş safhasında özellikle pist görüş mesafesi (Runway Visibility Reading - RVR) değerinin pilotlar tarafından bilinmesi gerekir. Bunun için gündüz "marker board"ları veya gece ise pist ışıklarını, iniş ve kalkış istikametinde görebilmek 


\section{European Journal of Science and Technology}

için pist eşiğinde 15 feet yükseklikten görülebilen en uzak mesafe, RVR olarak ölçülür. RVR, görüşün 1.500 metrenin altına düştüğünde ölçülür. Trafiğin durumuna göre 15 veya 30 dakikada bir transmissometer aleti kullanılarak ölçümler gerçekleştirilir. RVR değerleri, bulut alt tabanı yüksekliği, meydan teknik alt yapısı (ILS, Category Minimalarını karşılama vb.) ve iniş yapan uçağın teknik özellikleri ve nihayetinde pilotun eğitim seviyesi/meydan kategorisinde iniş yapabilecek ehliyet seviyesinde olduğunu gösteren kontrol belgesinin geçerli (current) olması gerekir (Atlas, 2012).

Bulut çeşitlerini havacılık açısından ele alırsak, satıhtan 6.500 feete kadar görülebilen ince tabaka şeklindeki stratus ve benzeri stratocumulus, nimbostratus bulutları, hem düşük görüşe hem de iniş ve kalkış paternlerinde bu bulutların içinden geçmek zorunda kalacak hava araçlarının içlerinde oluşan türbülans nedeniyle "sallanmasına", buzlanma, yağmur, kar gibi meteorolojik hadiselerin yaşanmasına, teknik olarak uçak sistemlerinin devreye sokulmadı̆̆ sistemlerinin olmaması, devreye sokulmaması vb.) kötü hava şartlarından etkilenebilecek uçak sistemlerinin uçuş esnasında "işlevini kaybetmesine" ve göstergelerin yanlış değer göstermesine ve benzeri problemlere sebebiyet verebilir. 6.500 ile 23.000 feet arasinda Altocumulus ve Altostratus bulutları bulunur. Özellikle altocumulus bulutlar içinde meydana gelebilecek şiddetli buzlanma nedeniyle bu bulutların içinden geçecek hava araçlarının teknik olarak tedbirli olmasını veya bu bulutların etrafindan dolaşarak rotasına devam etmesini gerektirebilir. 16.500 ile 45.000 feet arasında ise Cirrostratus, Cirrocumulus ve Cirrus bulutları yer alır. Havacılık açısından uçuş rotası boyunca en fazla dikkat edilmesi gereken bulut tipleri dikey bulutlardır. Bunlardan Cumulus bulutlar yerden 25.000 feete kadar, Cumulonimbus bulutlar yerden yaklaşık 33.000 feete kadar (tropopoz) ve Nimbostratus bulutları ise yerden 15.000 feete kadar uzanırlar (Jeppesen, 2004). Özellikle Cumulonimbus (uçucular ve meteoroloji uzmanları tarafından CB kısaltmasıyla ve çoğunlukla Oraj isimlendirmesiyle bilinir) tipi bulutlar, içinde şiddetli yağmur, kar firtınası ve dolu gibi şiddetli yağışın görülmesi nedeniyle önemlidir. Bu bulut tipleri uçaklar için büyük tehlike arz eder. Çoğunlukla bu bulutların içinden geçerken, uçaklar şiddetli buzlanmayla karşı karşıya kaldığı gibi şiddetli türbülans nedeniyle emniyetli uçuş şartlarının devam ettirilmesi, özellikle teknik imkânları zayıf ya da olmayan küçük uçaklarla yapılan uçuşlarda mümkün olamayabilir. $\mathrm{Bu}$ nedenle, büyük yolcu uçakları pilotları dâhil tüm uçucular; rota boyunca CB olduğuna dair meteorolojik uyarı varsa (yol kontrol, yer veya uçağın kendi meteoroloji radarı veya havadaki başka bir uçak tarafindan rapor edilmiş ise), mümkün olduğunca bu dikey bulutun etrafından, yaklaşık 20 millik bir mesafe (uçakla bulut arasında bırakılan mesafe) bırakarak rota değişikliği yaparlar ve bu şekilde uçuşa devam etmeyi tercih ederler. Thunderstorm da denen CB bulutlarının geçişleri esnasında, bu bulutlara 40 mil mesafeye kadar olan bölgelerde şiddetli rüzgar hadiseleriyle karşılaşmak söz konusudur. Hamleli rüzgara neden olan bu bulutlar, meydana inişe gelen uçakların iniş istikametine göre yandan bu rüzgara maruz kalması halinde pilotların uçaklarını indirmekte zorluk yaşamasına, bazı durumlarda uçağın emniyetli bir iniş yapamamasına ve pas geçilmesine neden olabilir. Özellikle küçük uçakların inişi neredeyse imkansız hale geleceğinden, rüzgarın sakin olduğu başka bir meydana gidilmesi (divert) gerekebilir. Zorunlu nedenlerle CB altından geçen uçaklar ise "microburst" denilen CB'nin merkezinden yere doğru esen şiddetli rüzgara maruz kalmalarına, uçuş irtifalarını tutmakta zorlanmalarına neden olabilir.
Buzlanma konusuna değinecek olursak, uçuşta buzlanma meydana geldiğinde hava aracının aerodinamik yapısında ciddi "geçici" değişiklikler oluşmaktadır. Kanat yapısında şekilsel bozulmaya neden olan buzlanma, uçağın diş geometrisinin bozulmasını da beraberinde getirir. Genel kabul olarak buzlanma olduğunda, uçağın kaldırması (Lift) \%30 azalırken, sürtünme (drag) \%40’a varan oranda artar ve uçağın buzlanmadan kaynaklı ağırlığı da artar (Jeppesen, 2004). Uçağın ağırlığının artması daha yüksek süratlerde uçağın stall olma eğilimini artırır, bu da uçuş emniyeti açısından istenmeyen bir durumdur. Aynı zamanda, buzlanmanın devam etmesi demek, artan sürtünme ve ağırlık nedeniyle uçağın yakıt sarfiyatının artması, bazı durumlarda planlanan varış meydanına erişemeden yakıtın bitmesine, bu nedenle rotadaki yakın bir meydana inilmesine neden olabilir. Havacılık endüstrisi kanat uçlarına, kanat ön kısımlarına (leading edge), motor hava alıklarına vb. uç noktalara "buza mani olucu" elektrikli bir nevi rezistanslar ile oluşan buzu önleyecek tedbirleri geliştirmiş, ısıtma yanında aynı uç yüzeylere çeşitli buz çözücü sıvı püskürtmek suretiyle buzun oluşmasını, oluşan buzun çözülmesini sağlayabilmektedir. Kalkış anında buzlanma şartları mevcutsa, meteoroloji raporlarında böyle bir ikaz varsa, de-icing ekipleri uçakların kalkış öncesinde kanatlarına uygun sıvı karışımlarını püskürterek, kalkışta uçakların sorun yaşamadan kalkması için gerekli teknik desteği verebilmektedir. Havada uçağın sürat, altimetre, dikey sürat göstergesi gibi aletlerinin çalışmasını sağlayan pitot tüpü ve statik girişlerin buzlanmaya karş1 korunması için günümüzde hemen hemen tüm modern uçaklarda bulunan probe de-ice (oluşan buzlanmayı çözme), antiice (buzlanmanın oluşmasını önleme) düğmelerine pilot tarafindan basılarak sistemler aktif hale getirilir. Unutmalara karşı, pilotu buzlanma olduğunda ikaz eden aktif bir sesli/1şıklı ikaz sistemi de uçaklarda mevcuttur.

Uçuculuğa etki eden diğer önemli bir meteorolojik olayda rüzgar kayması (Rüzgar Sheari)' dir. Rüzgar Sheari, atmosferde belirli iki nokta arasında rüzgarın hızında veya yönünde ya da her ikisinde meydana gelen yatay yada dikey ani değişiklikler olarak tanımlanabilir (ICAO, 2005). Bu meteorolojik olay; havaalanlarında uçuculuk için risk oluşturmaktadır. Özellikle Alçak seviyede meydana gelen Shear (Alçak Seviye Rüzgar Sheari) inişte, kalkışta ve pist boyunca uçaklar için tehlike arz edebilir. $\mathrm{Bu}$ noktalarda meydana gelen shear; inişte, enerji kazanımı veya kaybına, ani irtifa değişikliklerine, pisti kaçırmaya neden olurken, kalkışta ise, yine çok ani irtifa değişikliklerine enerji kaybına ve kalkış zorluklarına neden olabilmektedir (https://hezarfen.mgm.gov.tr/Aylik/gecmis/llwas/llwas.aspx

Dolayısı ile Rüzgar Sheari etkilerinin ve zararlarının azaltılması için havaalanlarına çeşitli sistemlerinin kurulup işletilmesi gerekmektedir. Bu sistemlerinin en başında da Alçak Seviye Rüzgar Sheari Uyarı Sistemi (LLWAS) gelmektedir. Dünyada sadece 6-7 havalimanında bulunan Alçak Seviye Rüzgar Kırılımı Uyarı Sistemi Türkiye'de ilk olarak Antalya Havalimanı'nda kurularak 2019 yılı Şubat ayında havacılık sektörünün hizmetine sunulmuştur. 


\section{Avrupa Bilim ve Teknoloji Dergisi}

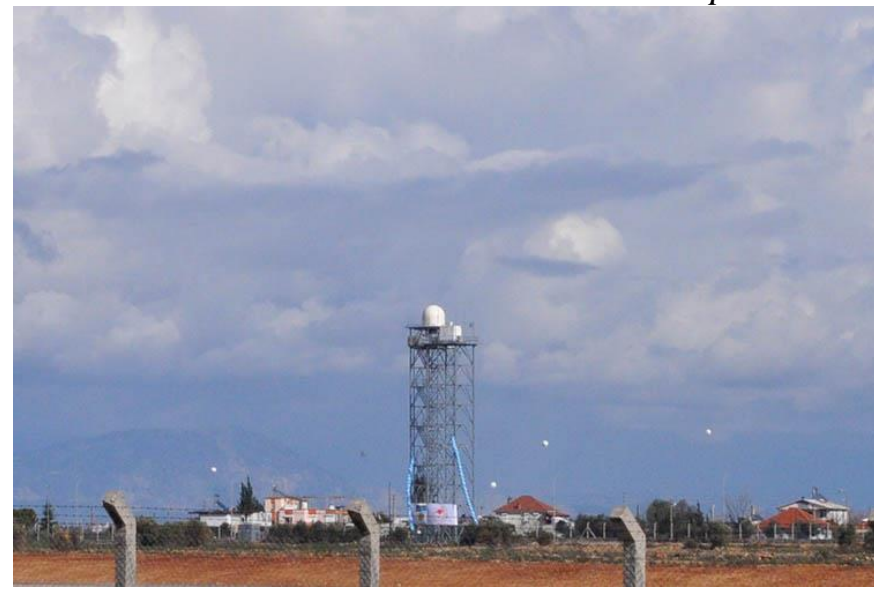

Şekil 1. Antalya Havalimanında İşletime Açılan Alçak Seviye Rüzgar Kesme Uyarı Sistemi (LLWAS)

Havacılık meteorolojisinin temel amacı ülkemizde ekonomik, askeri ve turistik alanlarda ihtiyaç duyulan hava seyrüseferinin emniyetli bir şekilde sağlanmasıdır. Havacılık meteorolojisi her türlü hava taşımacılığında ihtiyaç duyulan yaygın, güvenli, süratli ve standartlara uygun meteorolojik bilgilerle, bunların temin edilmesi için işletme ve planlama hizmetlerini kapsayan bir bilim dalıdır. Emniyetli bir hava seyrüseferi gerçekleştirmek için mevcut meteorolojik koşulların iyi analiz edilmesi ve gelecek hava koşullarının da en doğru şekilde tahmin edilmesi gerekmektedir. Dünya'nın her yerinde olduğu gibi ülkemizde de Meteoroloji Genel Müdürlüğü havacılık sektörüne doğru ve güvenilir bilgi sağlamak amacıyla çeşitli hizmetler sunmaktadır.

Meteoroloji Genel Müdürlüğü havacılık faaliyetlerine destek vermek amacıyla havacılık faaliyeti gerçekleştiren tüm meydanlara meteoroloji ofisleri kurmuştur. Uçuş faaliyetleri bakımından önem arz eden meteorolojik parametrelerin gözlemlenmesi amacıyla Uluslararası Sivil Havacılık Teşkilatının kriterlerine göre, her havaalanında ulusal veya uluslararası meteorolojik bilgi taleplerini karşılayabilecek en az bir meteoroloji ofisinin bulunması zorunludur. Meydanlardaki meteoroloji ofisleri belirli zaman aralıkları ile mevcut hava koşullarının rasatlarını yayınlarken aynı zamanda gelecek hava koşullarının da tahminlerini yayınlamaktadır. Meteoroloji ofislerinin dişında Meteoroloji Genel Müdürlüğü internet sitesinde (https://hezarfen.mgm.gov.tr/) uçuş planlama aşamasında kullanılacak radar görüntüsü, uydu görüntüsü, sinoptik haritalar, meteogram ve airgram çıktıları, yıldırım tespit ve takip sistemi, yukarı seviye hava kartları gibi pek çok bilgi kaynağı bulunmaktadır. Tablo 1.'de Meteorolojik Kaynakların hangi parametre ile ilgili olduğu ve hangi amaçlarla kullanıldığg gösterilmiştir. Mevcut kaynaklar konusunda dikkat edilmesi gereken en önemli husus ise model çıktıları ile elde edilen meteogram, airgram ve yukarı seviye kartlarının bir meteoroloji uzmanı tarafindan analiz edilerek mevcut topoğrafik koşullarda güvenilirliğinin değerlendirilmesidir.

Tablo 1. Meteorolojik Kaynaklar ve Kullanım Amaçları

\begin{tabular}{|c|c|c|}
\hline Meteolojik Kaynak & Meteorolojik Parametre & Kullanım Amacı \\
\hline Radar Görüntüsü & Yağ1ş & $\begin{array}{l}\text { Kısa vadeli hava tahmininde yağışın miktarı, türü ve meydan üzerine geliş̧ } \\
\text { zamanını tahmin etmek amacıyla kullanılır. }\end{array}$ \\
\hline Uydu Görüntüsü & Bulutluluk & $\begin{array}{l}\text { Kısa vadeli hava tahmininde bulutların tepe yüksekliğini, kapalılığını ve meydan } \\
\text { üzerine geliş zamanını tahmin etmek amacıyla kullanılır. }\end{array}$ \\
\hline \multirow{3}{*}{ Yukarı Seviye Kartı } & Buzlanma & Buzlanma seviyesi ve şiddetini tahmin etmek amaciyla kullanılır. \\
\hline & Türbülans & Türbülans seviyesi ve şiddetini tahmin etmek amacıyla kullanılır. \\
\hline & Bulut Türü & $\begin{array}{l}\text { Kümülonümbus ve tepe yapmış kümülüs bulutlarını tahmin etmek amacıyla } \\
\text { kullanılır. }\end{array}$ \\
\hline \multirow{4}{*}{ Sinoptik Haritalar } & Sicaklık & \multirow{4}{*}{$\begin{array}{l}\text { Sinoptik rasatlar sonucu elde edilen verilerin her bir sinoptik istasyon için } \\
\text { haritalara işlenmesi sonucu hava kütlesi hareketine göre gelecek hava durumu } \\
\text { ve cephesel geçişleri tahmin etmek amacıyla kullanılır. }\end{array}$} \\
\hline & Bulutluluk & \\
\hline & Rüzgar & \\
\hline & Nem & \\
\hline \multirow{6}{*}{ Meteogram ve Airgram } & Nem & \multirow{6}{*}{$\begin{array}{l}\text { Ait olduğu meydan ve çevresi için basıç, nem, yağış miktarı ve türü, bulut } \\
\text { kapalılığı ve bulut taban yükseklikleri, rüzgar yön ve şiddeti, rüzgar hamlesi, } \\
\text { sıcaklık ve çiğ noktası sıcaklığını tahmin etmek amacıyla kullanılır. Bu verilerin } \\
\text { elde edilmesi sonucunda görüş düşürücü hadise olan sis ve pus hadiselerinin } \\
\text { tahmini için gerekli bilgiyi sağlar. }\end{array}$} \\
\hline & Basınç & \\
\hline & Yağ1ş & \\
\hline & Bulutluluk & \\
\hline & Rüzgar & \\
\hline & Sicaklik & \\
\hline
\end{tabular}

Uçuş planlamaları öncesinde, uçuş yolu için sayısal tahmin bilgilerine, kalkış-iniş meydanları ile yol boyu gerektiğinde inilebilecek yedek meydanların hava durumlarına, önemli hava olaylarını rapor eden SWC girdilerine ihtiyaç bulunur. Uçağın kalkış ağırlığını tespit etmek için kalkış meydanı tahminlerine, özellikle rüzgar yönü ve şiddetine, sıcaklık değerine, basınç bilgilerinin pilotlara ve planlamacılara aktarılması gerekir. Yol boyunca hava yoğunluğundaki değişimler, şiddetli türbülans noktaları, buzlanma seviyeleri ve bölgeleri, oraj oluşumları ve diğer önemli olaylar kapsamındaki çeşitli meteorolojik bilgiler, pilotlara en güncel haliyle ulaştırılmalıdır. İniş meydanının ve yakınındaki yedek meydanların son hava tahminleri ve varsa gelişen tehlikeli bir hava hadisesi pilota yaklaşma radarları tarafından aktarılarak, pilotun en emniyetli şekilde planladığı 
European Journal of Science and Technology

meydana inmesi ve/veya yedek meydana yönelmesi (divert) beklenir.

Meteoroloji istasyonlarının bu kapsamda gözlemlerini (METAR) ve tahminlerini (TAF - Terminal Aerodrome Forecast) (istidlâl) pilotlara ve uçuş planlamacılarına belirli periyotlarla

iletmesi bir zorunluluktur. TAF, uçuş rotasında, bir bölgede veya bir meydanda beklenen meteorolojik hadiselerin belirli bir formatta, ön tahmin bilgilerini içeren periyodik meteoroloji raporudur. Havacılık amaçlı tahmin çeşitleri Tablo 2.'de özetle sunulmuştur.

Tablo 2. Havacılık Amaçlı Tahmin Çeşitleri (050 Meteoroloji, 2007)

\begin{tabular}{|l|l|l|}
\hline \multicolumn{1}{|c|}{ Tahmin Tipi } & \multicolumn{1}{c|}{ Kapsadığı Saha } & \multicolumn{1}{c|}{ Uçuş Planlama Safhası } \\
\hline 1) Meydan Tahmini (TAF) & Havaalanı & Uçuş öncesi ve uçuşta \\
\hline 2) İniş ve Kalkış Tahmini & $\begin{array}{l}\text { Havaalanı (Özellikle yaklaşma ve } \\
\text { touchdown zonu) }\end{array}$ & Uçuş öncesi ve uçuşta \\
\hline 3) Uçuş yolu Tahminleri & Yol Boyu & Uçuş öncesi ve uçuşta \\
\hline 4) SIGMET Bilgileri & FIR Sahası & Uçuş öncesi ve uçuşta \\
\hline 5) AIRMET Bilgileri & FIR Sahası & Uçuş öncesi ve uçuşta \\
\hline 6) Meydan İhbarları & Havaalanı Yer Şartları & Park eden uçaklar, Havaalanı inşaatları \\
\hline 7) Wind Shear İhbarları & $\begin{array}{l}\text { Havaalanı ve yaklaşma/kalkış path'i ile } \\
\text { pist arasındaki 500 m'lik seviye, ihtiyaç } \\
\text { halinde daha yüksek seviyeler }\end{array}$ & Uçuş esnasında, öncesinde ve kalkışta \\
\hline
\end{tabular}

Havacılık tahminleri belirli periyotlarda yapılmaktadır. Tablo 3.'de tahmin tipleri ve periyotları özetlenmiştir.

Tablo 3. Tahmin Periyotları (050 Meteoroloji, 2007)

\begin{tabular}{|l|l|}
\hline \multicolumn{1}{|c|}{ Tahmin Tipi } & \multicolumn{1}{c|}{ Periyodu } \\
\hline Havaalanı Tahmini (TAF) & $9,12,18$ veya 24 saat \\
\hline İniş Tahmini & 2 saat \\
\hline Kalkış Tahmini & Özel Periyod (Genellikle Kısa) \\
\hline Uçuş Yolu Tahminleri & $\begin{array}{l}\text { Kart formları halinde, belirli zaman aralıklarından, genellikle 0600, 1200, 1800 veya 2400 } \\
\text { UTC saatleri }\end{array}$ \\
\hline SIGMET Bilgileri & 6 saatten fazla değil ve tercihen 4 saatten fazla olmaması \\
\hline AIRMET Bilgileri & 6 saatten fazla değil ve tercihen 4 saatten fazla olmaması \\
\hline Meydan İhbarları & Genellikle 24 saatten fazla değil \\
\hline Wind Shear İhbarları & Beklenen Wind Shear periyodu kadar \\
\hline
\end{tabular}

Havacıllk sektörünün gelişmesi ve hava araçlarındaki çeşitliliğin artması ile meteorolojiye duyulan ihtiyaç günden güne artmaktadır. Her hava aracının meteorolojik koşullara karșı olan dayanma sınırları farklılık göstermekte ve uçuş planlaması sırasında bu değerler bilinerek en uygun uçuş rotasının oluşturulması gerekmektedir. Hava araçlarının farklı dayanma sınır değerlerinin olması sebebiyle meteorolojik analiz ve öngörülerin de daha hassas ve daha dar değer aralıklarında yapılması gerekmektedir. Örneğin; yukarı seviye hava kartları yolcu uçakları referans alınarak modellendiği için 10.000 feet seviyesini taban kabul etmekte ve bu seviyenin altında buzlanma ve türbülans bilgisi vermemektedir.

Günümüz havacılık sektöründe oldukça önemli bir yere sahip olan insansız hava araçlarının 10.000 feet irtifaya tırmanma süreleri yolcu uçaklarına kıyasla daha uzun sürdüğü için 10.000 feet ve aşağısında meydana gelebilecek buzlanma ve türbülans koşulları insansız hava araçları için son derece önem arz etmektedir. Aynı durum helikopter trafiği için daha da büyük önem arz etmektedir. Buzlanma ve türbülans bilgileri mevcut konuma özgü olarak meydan meteoroloji ofisleri tarafindan Skew-T diyagramları kullanılarak pilotlara verilmektedir. Şekil 1'de Skew-T diyagramı ve üzerindeki sıcaklık, basınç, kuru ve nem adyabatlar, karışma oranı çizgileri gösterilmektedir.

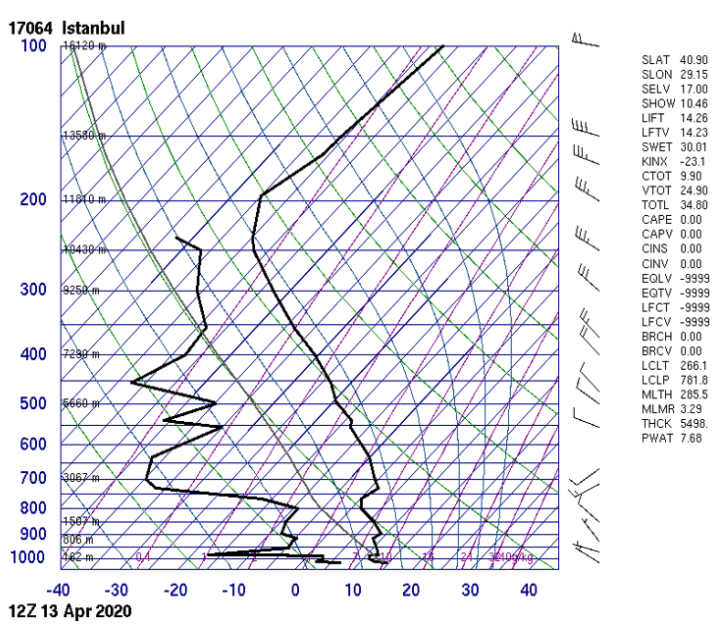

Şekil 2. Skew-T Diyagramı (Skew-T Log-P diagrams, 2020)

Skew-T diyagramları ülkemizde 8 meydanda gerçekleşen ravinsonde rasatları sonucu oluşturulmakta ve oluşturulan bu çiktılar modellere işlenerek ülkemizdeki her bir konum için Skew-T model çıktısı elde edilmektedir. Ravinsonde cihazının bir balonla birlikte atmosfere bırakılarak basınç, sıcaklık, nem, rüzgâr değerlerini ölçmesi ve eş zamanlı olarak yerdeki istasyona 


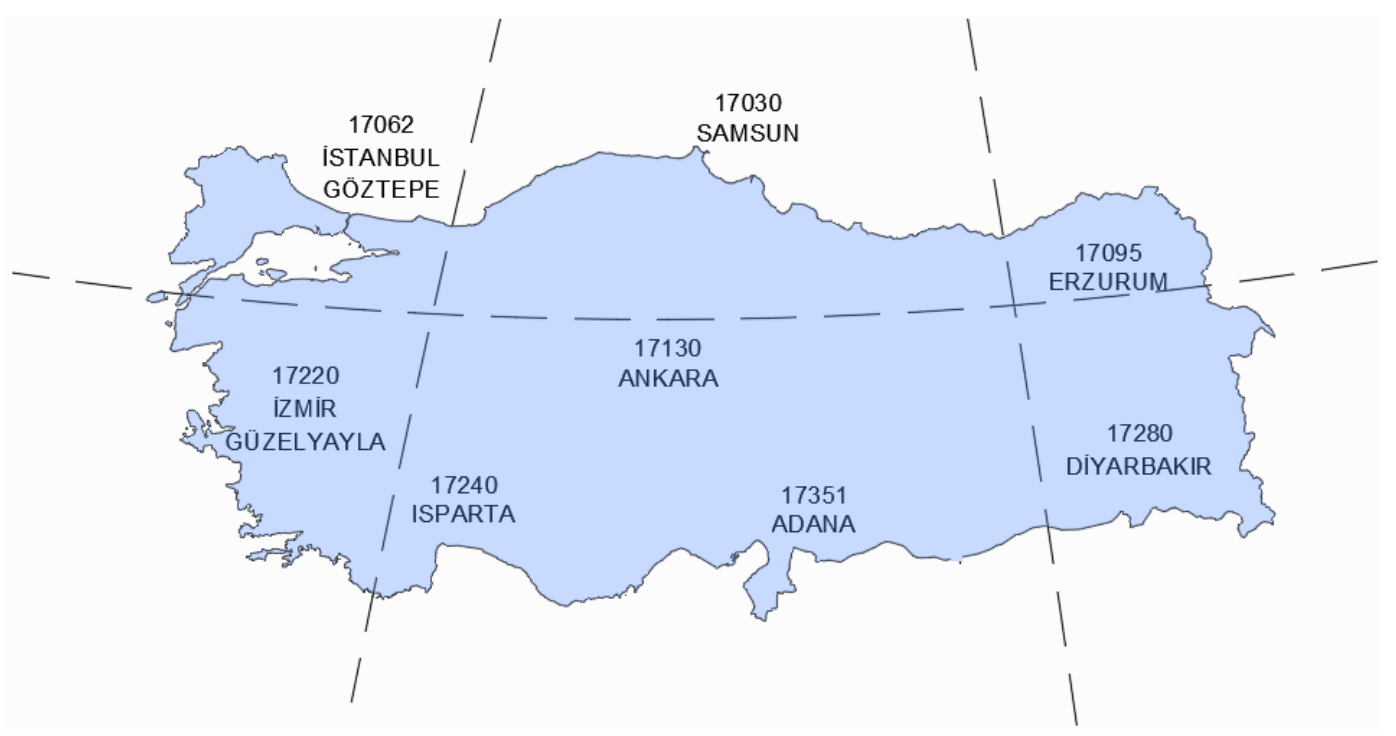

Şekil 3. Türkiye Ravinsonde İstasyonları ve WMO Numaraları (MGM, 2020)

Öte yandan, meteoroloji ofislerinin tahmin periyotları 9 saatten az ve 24 saatten fazla olamamakta ve her meydan 24 saatlik tahmin yayınlayamamaktadır. İnsansız hava araçlarının havada uçuş süreleri ile yolcu uçaklarının uçuş süreleri farklılık göstermektedir. İnsansız hava araçlarının havada kalma süreleri 24 saat ve daha fazla sürebilmektedir. Bu nedenle meydan tahminlerinin yanı sıra diğer meteorolojik çıktıların da uçuş planlamasındaki önemi büyüktür.

Gelişen havacılık sektörüne ve hava araçlarının meteorolojik ihtiyaçlarına daha fazla katkı sağlamak ve gereksinimleri karşılamak amacıyla Meteoroloji Genel Müdürlügü̈ özellikle insansız hava araçlarına daha iyi bir destek vermek amaciyla belirli kurallarda değişikliklere gitmekte ve bu değişiklikler uçuş emniyetine katkı sağlamaktadır. Örneğin, insansız hava araçlarının yoğun olduğu meydanlarda bütün bulutluluk bilgisine sahip olmak amaciyla meydan rasat kodlarından CAVOK kısaltması çıkartılmıştır. Meydan limitinin altında veya 5.000 feet altında herhangi bir bulut olmaması, görüş mesafesinin $10 \mathrm{~km}$ ve üzerinde olması, meydan civarında (15 km içinde) $\mathrm{CB}$ türü bulutların olmamasi durumunda CAVOK kisaltması kullanılmaktadır (050 Meteoroloji, 2007). CAVOK kısaltması görüş ve bulut tabanı uçuş limitlerine uygun (cealing and visibility okey) anlamına gelmektedir. Böylece havadaki bulutlar ve kapalılık durumu ile ilgili bilgi yayınlanmakta ve buna göre hava koşullarının insansız hava araçları için uçuşa elverişli olup olmadığına karar verilmektedir.

Pilotlar, uçuş plancıları, meteoroloji uzmanları gibi meteorolojik hadiseler ve hava tahminleri çerçevesinde işlerini yapan kullanıcılar arasında havacıllk meteorolojisine yönelik özel ve ortak bir dil anlamında bir terminoloji geliştirilmiş̧tir. Örneğin bulutluluk için kullanılan terimler vardır: SKC (Sky Clear, Bulut Yok), FEW (Gökyüzünün 2/8'i bulutla kapl1), SCT (Scattered, Gökyüzü parçalı bulutlu, 4/8'i bulutla kaplı), BKN (Broken, Gökyüzünü 7/8'e kadarı, neredeyse tamamı bulutla kaplı) ve son olarak OVC (Overcast, gözyüzünün $8 / 8$ 'i, yani tamamı bulutla kaplı demektir) gibi terimler kapalılık için kullanılır (050
Meteoroloji, 2007). Buna benzer çeşitli kısaltmalar ve terimler yaygın olarak hava raporlarında yer alır.

Bu bölümde havacıllkta meteoroloji uygulamaları ve önemi çok net olarak verilmiştir. Her bilim dalında olduğu gibi meteoroloji sistemleri ve teknik donanımları her geçen gün iyileşmekte, yeni cihazlar geliş̧irilmektedir. $\mathrm{Bu}$ konuda da maalesef ülkemiz dışa bağımlıdır. Havacılık için elzem olan bu cihazlardaki teknolojileri anlamak ve bu teknolojileri daha ileri seviye götürmek zorunludur. Eğer güçlü bir havacılık istiyorsak meteoroloji alanındaki çalışmaları desteklemeliyiz. Aynı zamanda teknik gelişmeleri yakından takip etmek zorundayız. Yoksa sadece kullanıcı olmak çok fazla bir şey ifade etmez. Meteoroloji Genel Müdürlüğü de üyesi olduğu uluslararası kuruluşlarla (EUMETSAT, ECMWF, WMO) meteoroloji konusundaki bilimsel ve teknik gelişmeleri yakından takip etmektedir.

\section{Meteoroloji ve Havacılıkta Ortak Stratejiler}

Yukarda verilen bilgiler ışığında çok net olarak havacılık ve meteoroloji arasında çok önemli ilişkiler bulunmaktadır. İki yapı birbirini destekleyen olmazsa olmaz ikililerdendir. Genelde değerlendirmeler operasyon anlamında daha çok göze çarpmaktadır. Hava araçlarının istenen performansı sağlayabilmesi için ideal hava şartlarında uçurulması gerekmektedir. Uçuşa sağlanan verileri doğru ve güvenilir olması şarttır. Gerçek zamanlı hızlı veri akışı çok büyük öneme sahiptir. Hava şartlarına göre operasyon şartları belirlenmeli ve o şartlara göre planlama yapılmalıdır. Bunun yanında havacılıkta veya herhangi bir sektör için yatırımlar söz konusu olduğunda da bölgenin meteorolojik durumu göz önünde bulundurulmalıdır. Yoksa uzun vadede ciddi maliyetlerle karşı karşıya kalınabilir. Kışın çok yoğun geçtiği, türbülansın çok fazla olduğu, sisin hiç eksik olmadığı bir bölgede havaalanı ne kadar etkin kullanılabilir? Hava araçlarının testleri nasıl sağlıklı bir şekilde yapılabilir? Yılın ne kadar zamanında uçuş testleri yapılabilir? Bu soruların anlamlı cevapları olması gerekmektedir. Yapılan yatırımdan nasıl verim 


\section{European Journal of Science and Technology}

alınabilir? Bütün bu faktörler 1şı̆̆ında devletimizin veya özel sektörün yapacağı hemen hemen bütün yatırımlarda özellikle hava araçlarının üretim tesislerinin kurulacağı bölgelerde meteoroloji raporları çok dikkate alınmalıdır. Hem verimlilik hem maliyet hem de uçuş emniyeti açısından çok önemlidir. Tabi ki ülkemizde bu raporlar hazırlanmaktadır fakat raporların hazırlanmasında daha fazla hassasiyet gösterilmeli yeterli veri ile rapor desteklenmelidir. Ulusal Meteoroloji Stratejilerimiz güncel olmalı uluslararası stratejilerle uyumluluk göstermelidir. Stratejilere hassasiyetle uyulmalı belirlenen hedefler mutlaka ulaşılmalıdır. Stratejiler doküman olarak kalmamalı bilfiil sahada uygulanmalıdır. Yatırım stratejileri belirlenirken mutlaka bölgeyle ilgili yeterli miktarda meteorolojik veriler kullanılmalıdır. Somut bir örnek verilecek olursa birçok bölgeye yatırım yapılırken bölgenin hava şartları, mevsimlerin sağladığ avantajlar, tesisin maksimum kullanılabilme kabiliyeti gibi birçok özelliği dikkate alınmamaktadır. Bu durum da uzun vadede verimliği azaltmakta ve maliyetleri arttırmaktadır. $\mathrm{Bu}$ örneklerden birisi eğlence (luna) parklarıdır. Bu parklar inşa edilirken iklim şartları dikkate alınmadığında yılın büyük bir bölümü park kullanılamamakta, bakım masrafları yüksek olmakta ve yatırımın verimliliği düşmektedir.

Gelişmiş ülkelerde hava trafiği her geçen gün hızla artmaktadır. Hava araçları yakıt sarfiyatı anlamında çok ciddi manada tüketicilerdir. Çevre kirliliğine neden olan karbondioksit salınımı yanı sıra havaya su buharı ve nitrik asit de bırakmakta, küresel 1sınmayı tetikleyici olumsuz etkenlerden biridir. Uçak yakıtı, diğer adıyla kerosen, yüzde 86 karbon ve yüzde 14 hidrojenden oluşuyor. Karbon yanma sirasında havadaki oksijenle birleştiği için bir uçağın yaktığı her bir kilogram kerosen için türbinlerden 3,15 kilogram karbondioksit atmosfere salınıyor.

Diğer önemli bir hususta ülkemiz gibi enerji konusunda dişa bağımlı ülkelerde yakıt tasarrufları çok büyük öneme sahiptir. En basit şekliyle hava şartlarının iyi olduğu bölgelere havaalanları kurmak, hava araçları üreten şirketlerin test faaliyetlerini uçuş şartlarının en iyi olduğu bölgelerde yapmak hem yakıt hem de uçuş emniyeti açısından çok büyük öneme sahiptir. Bu doğrultuda Meteoroloji Genel Müdürlüğü bünyesinde politikalar geliştirilmeli ve bu politikalar devletin en üst makamı tarafindan zorunlu hale getirilmelidir. Kaynakların etkin ve verimli kullanılması bakımından çok büyük öneme sahiptir. Ulusal Meteoroloji Stratejisinin yatırımlarda göz önünde bulundurulması ve devlet gücüyle istisnasız uygulanması gereklidir.

\section{Sonuç}

Havacılık, meteorolojik olaylara son derece duyarlı bir sektördür. Günümüzde uçuşların daha emniyetli ve konforlu olması için uçuş planlamaları, meteorolojik koşullar göz önünde bulundurularak hazırlanmaktadır. Meteoroloji havacılık işletme ve planlama hizmetlerinin önemli bir parçası haline getirmiştir. $\mathrm{Bu}$ çalışmada uçuş planlaması yapılırken uçuş emniyetini sağlamak amaciyla meteorolojik bilgi ve değerlendirmelerin çok büyük öneme sahip olduğu açıkça görülmüştür. Hava trafiğinin olumsuz hava koşulları nedeniyle sekteye uğramaması için planlama ve işletme stratejilerinin yanı sıra, pilotlar ve hava trafik kontrolörleri için meteorolojik veriler oldukça önemlidir. Emniyetli, konforlu ve ekonomik uçuş için meteorolojiyle uyumlu planlamalar yapılması gerektiği vurgulanmıştır. Havacılık ve meteoroloji birbirinden ayrılmaz bir ikili olarak değerlendirilmelidir. Ortak politikalar belirlenmesi oldukça büyük öneme sahiptir.
Havacılık sektöründe gelinen son nokta göstermektedir ki, havacılık teknolojisindeki gelişmeler havacılık faaliyetleri için gerekli meteorolojik bilgilerin giderek daha da önemli hale geleceğini bize ifade etmektedir. Havacılık yatırımları yapılırken meteorolojik bilgiler ile uyumlu yatırımlar yapılmalıdır.

Meteoroloji altyapısı da havacılık sektörünün ihtiyaçlarına göre yapılandırılmalı ve güncellenmelidir. Havacılığın hâlihazırdaki ve gelecekteki ihtiyaçları güvenilir bir şekilde karşılanabilmesi için meteorolojik altyapı bilimsel ve teknolojik gelişmeleri dikkate alarak tasarlanmalıdır. Son olarak havacılık özelinde de ulusal meteoroloji stratejisi geliştirilmeli ve uygulanmalidir.

\section{Kaynaklar}

Atlas (2012) The Pilots' Free Flight Atlas, Absolutezero Multimedia, ISBN 3-00-003648-2, www.absolutezero.de.

Dervişoğlu, F. (2014). İstikbalini Göklerde Arayan Ülke ve Türk Havacılık Sahasında Alman Menfaatleri Işığında Bir Ortaklık: Tomtaş. Cumhuriyet International Journal of Education, 3(3), 68-82. doi:10.30703/cije.321351.

Gök, Kerem. (2015). Türk Sivil Havacılık Tarihine Damgasını Vuran Uçak Kazaları, Altın Bilek Yayınları, İstanbul

Havacılık ve Meteoroloji. (n.d.). https://uteddergi.com/havacilikve-meteoroloji/ web sayfasından alınmıștır (02.04.2020).

Jeppesen Meteorology (2004) JAA ATPL Training, Jeppesen Sanderson Inc., ISBN 0.88487.350.1 (www.jeppesen.com)

MGM. (n.d.). Sikça Sorulan Sorular - Meteoroloji Genel Müdürlüğü.

https://www.mgm.gov.tr/genel/sss.aspx?s=ravinsonde web sayfasından alınmıştır (05.04.2020).

Pooley, Dorothy, ve David Robson. The Air Pilot's Manual 3: Air Navigation: Pooley's Air Pilot Publishing, 2010.

Skew-T Log-P diagrams. (n.d.) https://www.weather.gov/jetstream/skewt web sayfasindan alınmıştır (05.04.2020).

Yalçın, Osman. (2010). Türk Devleti'nin Uçak Fabrikası Kurma Mücadelesinde İlk Girişim: Tayyare ve Motor Türk Anonim Şirketi (TOMTAŞ) ve Kayseri Uçak Fabrikası. Atatürk Araştırma Merkezi Dergisi, 26 (78), 561 - 588.

050 Meteoroloji (2007) Meteoroloji Ders Kitabı, Türk Hava Kuvvetleri 2 nci Ana Jet Üs Komutanlığı Yayınları (1.Baskı).

Türk Hava Kuvvetleri UÇAKLARI. Turkish air forces AIRCRAFTS.

https://www.tayyareci.com/digerucaklar/turkiye/index.asp web sayfasından alınmıştır (07.04.2020).

tusas.com, https://www.tusas.com/kurumsal/hakkimizda web sayfasından alınmıştır (10.04.2020).

ICAO (2005) Doc 9817 AN/449 Manual on Low Level Wind Shear - First Edition. 